\title{
Pengaruh penerapan model discovery learning berbasis multiple intelligences terhadap kemampuan pemahaman matematis peserta didik
}

\author{
Tiya Fathonah, Satya Santika, Ebih Abdul Rachim Arhasy \\ Jurusan Pendidikan Matematika, Fakultas Keguruan dan Ilmu Pendidikan, \\ Universitas Siliwangi, Tasikmalaya, Indonesia \\ E-mail: tiyafathonah@gmail.com
}

\begin{abstract}
ABSTRAK
Penelitian ini bertujuan untuk mengetahui pengaruh penerapan model Discovery Learning berbasis Multiple Intelligences terhadap kemampuan pemahaman matematis peserta didik dan untuk mengetahui minat belajar matematika peserta didik setelah menerapkan pembelajaran model Discovery Learning berbasis Multiple Intelligences. Penelitian ini memakai metode eksperimen dengan populasi sebanyak 312 peserta didik kelas VIII SMP Negeri 13 Tasikmalaya tahun pelajaran 2018/2019. Sampel ditentukan secara Cluster Random Sampling. Kelas VIII-I yang berjumlah 32 orang terpilih sebagai kelas eksperimen yang pembelajarannya menerapkan model Discovery Learning berbasis Multiple Intelligences, sedangkan kelas VIII-H yang berjumlah 31 orang terpilih sebagai kelas kontrol yang pembelajarannya menerapkan model Discovery Learning. Pengumpulan data penelitian ditentukan menggunakan tes kemampuan pemahaman matematis berbentuk uraian (postest). Instrumen penelitian ini terdiri dari soal tes kemampuan pemahaman matematis dan angket minat belajar matematika peserta didik. Teknik analisis data menggunakan uji perbedaan dua rata-rata. Hasil penelitian menunjukkan ada pengaruh penerapan model Discovery Learning berbasis Multiple Intelligences terhadap kemampuan pemahaman matematis peserta didik dengan minat belajar matematika peserta didik berada pada kategori tinggi.
\end{abstract}

Kata Kunci : Discovery Learning, Kemampuan Pemahaman Matematis, Minat Belajar, Multiple Intelligences.

\begin{abstract}
This study aims to determine the effect of the application of Multiple Intelligences based Discovery Learning on students mathematical understanding ability and to find out the interest in learning mathematics of students after applying Multiple Intelligences based Discovery Learning. This study uses an experimental method with population of 312 eighth grade students of SMP Negeri 13 Tasikmalaya in the academic year 2018/2019. The sample is determined by cluster random sampling. 32 students from VIII-I class was chosen as the experimental class whose learning applied the Multiple Intelligences based Discovery Learning, while the VIII-H class which numbered 31 students was chosen as the control class whose learning applied the Discovery Learning model. The collection of research data is determined through a single test of mathematical understanding ability in the form of a description (posttest). The instrument of this study consisted of test questions of mathematical comprehension ability and students interest in learning mathematics. The data analysis technique uses the two average difference test. The results showed that there was an effect of the application of Multiple Intelligences based Discovery Learning models to the students 'mathematical understanding ability with students interest in mathematics learning in the high category.
\end{abstract}

Keywords: Discovery Learning, Mathematical Understanding Ability, Learning Interest, Multiple Intelligences.

\section{PENDAHULUAN}

Matematika merupakan suatu ilmu yang mempunyai konsep, aturan, dan prosedur. Kegunaan matematika sangat erat kaitannya dengan kehidupan, sehingga setiap manusia diharapkan dapat menguasainya. Penguasaan matematika dapat diperoleh melalui pendidikan. 
Pelajaran matematika mempunyai sifat terurut, bertingkat, dan berkelanjutan. Oleh karena itu, dasar keberhasilan penguasaan matematika adalah kemampuan pemahaman matematisnya. Menurut hasil studi pendahuluan terhadap siswa kelas VIII di salah satu SMP Kota Tasikmalayapada tahun pelajaran 2018/ 2019, sebagian siswa di sekolah tersebut maish menganggap materi Geometri sulit. Pengalamannya menggambarkan dalam proses pembelajaran matematika, peserta didik belum memahami penggunaan simbol-simbol pada pembelajaran matematika, belum mampu melaksanakan suatu strategi penyelesaian yang telah dicontohkan, menterjemahkan ataupun menyajikan situasi matematika ke dalam situasi lainnya (representasi), menghasilkan jawaban dari permasalahan yang diberikan dengan berbagai cara, mengkaji kembali ataupun membuktikan jawaban yang telah diperolehnya, menyelesaikan permasalahan yang sedikit berbeda dari contoh, dan menyimpulkan permasalahan yang telah diberikan. Hanya sebagian kecil yang mempunyai rasa keberanian untuk menyajikan kembali hasil belajarnya dan cenderung melupakan materi terdahulu, sehingga kesulitan untuk menerangkan konsep yang telah dimilikinya yaitu materi prasyarat yang selalu terhubung satu dengan lainnya. Semua itu, membuat peserta didik belum berani mengemukakan pendapatnya dalam pelajaran matematika.

Hasil observasi menunjukkan karakteristik peserta didik dan kondisi kelas secara langsung, diperoleh informasi bahwa peserta didik kelas VIII tahun pelajaran 2018/ 2019 di kedua sekolah tersebut pada setiap kelasnya dihuni oleh peserta didik yang memiliki karakteristik yang beragam di setiap individunya. Jika ditinjau dari lokasinya, sekolah yang disebutkan pertama kali dalam penelitian ini terletak di perbatasan Kota Tasikmalaya sehingga berpotensi juga diisi oleh masyarakat dari luar kota. Jadi latar belakang dari masing-masing peserta didiknya juga beragam.

Berdasarkan hasil wawancara dan observasi di dua sekolah tersebut, peneliti mengadakan penelitian di SMP Negeri 13 Tasikmalaya. Hal ini berdasarkan kurangnya pemahaman matematis peserta didik di sekolah tersebut, karena dampak dari kurangnya pemahaman matematis sangat berkaitan erat dengan pengembangan kemampuan-kemampuan matematis lainnya. Hal ini sejalan dengan pendapat Hendriana, Rohaeti, dan Sumarmo (2017) yang menyatakan bahwa kemampuan pemahaman matematis merupakan dasar pendukung untuk mengembangkan kemampuan-kemampuan matematis lainnya (pp.3-4). Kemampuan pemahaman matematis dikelompokkan menjadi beberapa jenis, penelitian tentang kemampuan pemahaman matematis juga telah banyak dilakukan dengan jenis yang beragam. Penelitian tersebut antara lain tentang penerapan, kemampuan pemahaman konsep matematis peserta didik dengan menggunakan model discovery learning (Mawaddah \& Maryanti, 2016). Selain itu, kemampuan pemahaman matematis juga telah dianalisis, salah satu penelitiannya adalah analisis pemahaman matematis peserta didik menurut Polya dengan pemberian scaffolding (Safitri, Susanto, \& Fatahillah, 2017).

Berdasarkan penelitian-penelitian yang telah dilakukan, penelitian ini membahas jenis kemampuan pemahaman matematis yang dikemukakan oleh Polya. Sumarmo (dalam Hendriana, et al., 2017)menyebutkan jenis kemampuan pemahaman matematis Polya, antara lain pemahaman mekanikal, pemahaman induktif, pemahaman rasional, dan pemahaman intuitif. Setiap individu manusia memiliki keberagaman potensi intelektual maupun bakat khusus yang bersifat keterampilan. Sehingga dalam proses belajar mengajar secara klasikal, baiknya tidak menganggap semua peserta didik yang ada di dalam kelas dipandang sebagai pribadi yang homogen. Oleh karena itu, strategi pendidikan perlu secara khusus memperhatikan pengembangan potensi peserta didik yang memiliki bakat dan kecerdasan yang berbeda- beda.

Multiple Intelligences (kecerdasan majemuk) merupakan pembelajaran yang memperhatikan 
berbagai kecerdasan yang dimiliki oleh setiap peserta didik. Hal ini sejalan dengan pendapat Gardner (2003) yang menjelaskan bahwa, Multiple Intelligences adalah sebuah penilaian yang menggambarkan individu manusia dalam menggunakan kecerdasannya untuk memecahkan masalah dan menghasilkan sesuatu. Multiple Intelligences juga dapat dijadikan sebagai dasar peninjauan terhadap kemampuan matematis peserta didik. Berbagai macam Multiple Intelligences manusia dikategorikan oleh Gardner (dalam Uno \& Kuadrat, 2014) menjadi delapan kecerdasan dasar antara lain, linguistic intelligence, logical mathematical intelligence, visual spatial intelligence, bodily kinesthetic intelligence, musical intelligence, interpersonal intelligence, intrapersonal intelligence, dan naturalis intelligence.

Pembelajaran berbasis Multiple Intelligences juga telah banyak diteliti dan dikembangkan dengan cara mengkombinasikannya dengan model pembelajaran lainnya. Penelitian tersebut antara lain, hubungan kemampuan pemahaman matematis dengan Multiple Intelligences (Ariany, Rachmawati, \& Agustina, 2017), pembelajaran matematika berbasis kecerdasan majemuk (Sunendar, 2018), pengaruh penggunaan pembelajaran berbasis Multiple Intelligences terhadap kemampuan pemecahan masalah (Ratnasari, 2014), efektivitas pembelajaran berbasis kecerdasan majemuk ditinjau dari keyakinan siswa terhadap matematika dan prestasi belajar (Dwiyana, 2017), pengaruh pendekatan Problem Based Learning (PBL) berbasis Multiple Intelligences terhadap kemampuan pemecahan masalah matematis (Hasanah, Sudin, \& Maulana, 2017). Berdasarkan penelitian-penelitian terdahulu yang telah dipaparkan, keterbaruan dari penelitian ini adalah menerapkan model Discovery Learning berbasis Multiple Intelligences.

Peserta didik dengan latar belakang kecerdasan berbeda-beda memiliki rasa atusiasme dalam belajar yang berbeda-beda pula. Kadar antusiasme peserta didik dalam proses belajar dapat dikatakan sebagai minat belajar. Minat belajar yang tinggi akan memudahkan peserta didik untuk mencapai tujuan belajar, sedangkan kurangnya minat belajar dapat mengakibatkan kurangnya rasa ketertarikan seseorang terhadap pembelajaran. Hal ini sejalan dengan pendapat yang dikemukakan oleh Susanto (2016) yang mengemukakan bahwa minat memegang peranan penting dalam belajar, karena merupakan suatu kekuatan motivasi yang menyebabkan seseorang memusatkan perhatiannya terhadap kegiatan belajar (p.66). Penelitian tentang minat terhadap kemampuan matematis telah dilakukan, salah satunya adalah pengaruh kecerdasan emosional dan minat belajar terhadap penguasaan konsep matematika (Gusniwati, 2015). Berdasarkan penelitian terdahulu tersebut, penelitian ini membahas minat belajar matematika dengan menerapkan model Discovery Learning berbasis Multiple Intelligences terhadap kemampuan pemahaman matematis.

Untuk memastikan keterlibatan aktif sebagai tanda tingginya minat belajar tersebut, diperlukan sebuah tatanan kegiatan kelas yang memicu semangat belajarnya serta mendorong mereka untuk berbuat sesuatu yang ditujukan untuk menggali dan mengembangkan potensi yang mereka miliki. Salah satu usaha yang dapat dilakukan oleh pendidik adalah dengan menggunakan model pembelajaran yang tepat, seperti penelitian tentang efektivitas model pembelajaran discovery dengan setting kooperatif ditinjau dari kemampuan analogi dan generalisasi matematis (Dassa, Tahmir, \& Magfirah, 2017). Berdasarkan pemaparan penelitian terdahulu, penelitian ini juga akan menganalisis minat belajar matematika peserta didik sebagai pengaruh yang ditimbulkan dari penerapan model Discovery Learning berbasis Multiple Intelligences.

Salah satu model pembelajaran yang direkomendasikan oleh Kurikulum 2013 dan membuka ruang bagi pendidik untuk melibatkan peserta didik agar aktif serta menemukan makna di setiap pembelajarannya adalah model Discovery Learning. Model pembelajaran tersebut juga dapat dihubungkan dengan kemampuan pemahaman matematis. Model Discovery Learning 
terdiri dari beberapa fase yang memberikan kesempatan peserta didik untuk memperoleh penagalaman belajar melalui proses penemuan, Illahi (2012) menyebutkan diantaranya stimulation yang dapat memberikan motivasi peserta didik untuk belajar, problem statement bertujuan untuk mengenalkan dan melatih peserta didik dalam menghadapi permasalahan matematika, data collection mengupayakan peserta didik untuk mencari berbagai data yang diperlukan, data processing melatih peserta didik untuk mengolah dan menerapkan data atau konsep yang telah dimilikinya, verification dapat membiasakan peserta didik untuk mengkaji kembali hasil yang telah didapatkannya dari proses pengolahan dan penerapan yang telah dilakukannya, dan generalization mengupayakan peserta didik untuk mengambil kesimpulan dari kegiatan pembelajarannya. (pp.87- 88). Berdasarkan pemaparan tersebut, maka peneliti melakukan penelitian tentang Pengaruh Penerapan Model Discovery Learning Berbasis Multiple Intelligences Terhadap Kemampuan Pemahaman Matematis Peserta Didik (Penelitian dilakukan di Kelas VIII SMP Negeri 13 Tasikmalaya).

\section{METODE PENELITIAN}

Penelitian ini menggunakan metode eksperimen untuk mengetahui sebab akibat dari penerapan model Discovery Learning berbasis Multiple Intelligences terhadap kemampuan pemahaman matematis peserta didik. Populasi penelitian melibatkan seluruh peserta didik kelas VIII tahun pelajaran 2018/ 2019 di SMP Negeri 13 Tasikmalaya. Terpilih kelas VIII-I (kelas eksperimen) dan kelas VIII-H (kelas kontrol) sebagai sampel penelitian yang diperoleh melalui cluster sampling. Kelas eksperimen merupakan kelas yang dalam pembelajarannya menerapkan model Discovery Learning berbasis Multiple Intelligences, sedangkan kelas kontrol menerapkan pembelajaran Discovery Learning. Desain penelitian ini menggunakan posttetst-only control design, yang setiap sampel diberi tes kemampuan pemahaman matematis. Pada kelas eksperimen juga disebarkan angket untuk mengetahui minat belajar matematika setelah penerapan model Discovery Learning berbasis Multiple Intelligences. Teknik analisis data menggunakan uji perbedaan dua rata-rata. Sedangkan angket minat belajar matematika dianalisis berdasarkan kategori diagnosis yang terdiri dari tiga jenis, yaitu tinggi, sedang, dan rendah.

\section{HASIL DAN PEMBAHASAN}

Pelaksanaan pembelajaran matematika di kelas eksperimen dan kelas kontrol dilaksanakan sebanyak enam kali pertemuan. Distribusi pengelompokan atau kriteria penilaian kemampuan pemahaman matematis yang disajikan ke dalam Tabel 1.

Tabel 1. Hasil Penilaian Tes Kemampuan Pemahaman Matematis Peserta Didik secara Keseluruhan

\begin{tabular}{llll}
\hline Interval & Kategori & Kelas Eksperimen & Kelas Kontrol \\
\hline A & Sangat baik & $28,13 \%$ & $22,58 \%$ \\
\hline B & Baik & $56,25 \%$ & $41,93 \%$ \\
\hline C & Sedang & $12,5 \%$ & $22,58 \%$ \\
\hline D & Kurang & $3,12 \%$ & $9,68 \%$ \\
\hline E & Sangat kurang & $0 \%$ & $3,23 \%$ \\
\hline
\end{tabular}


Kemampuan pemahaman matematis paling rendah berada pada kategori kurangyaitu 3,45\%. Hal ini menunjukkan bahwa hasil penelitian ini masih rendah jika dibandingkan dengan hasil penelitian Mawaddah dan Maryanti (2016). Kemampuan pemahaman matematis pada penelitian ini diukur dari empat indikator, yaitu pemahaman mekanikal, pemahaman induktif, pemahaman rasional, dan pemahaman intutif. Hasil penilaian tes kemampuan pemahaman matematis peserta didik berdasarkan indikator di kelas eksperimen dapat disajikan ke dalam Tabel 2, sebagai berikut:

Tabel 2. Hasil Penilaian Tes Kemampuan Pemahaman Matematis Peserta Didik Berdasarkan Indikator Kemampuan Pemahaman Matematis

\begin{tabular}{llrrrrrrrr}
\hline \multirow{2}{*}{ Int } & Kategori & \multicolumn{2}{c}{ Mekanikal } & \multicolumn{2}{c}{ Induktif } & \multicolumn{2}{c}{ Rasional } & \multicolumn{2}{c}{ Intuitif } \\
\cline { 2 - 10 } & & $\mathrm{E}$ & $\mathrm{K}$ & $\mathrm{E}$ & $\mathrm{K}$ & $\mathrm{E}$ & $\mathrm{K}$ & $\mathrm{E}$ & $\mathrm{K}$ \\
\hline A & Sangat baik & 84,38 & 74,19 & 37,5 & 48,39 & 37,5 & 22,58 & 25 & 16,12 \\
\hline $\mathrm{B}$ & Baik & 15,63 & 22,58 & 43,75 & 32,26 & 43,75 & 48,39 & 37,5 & 16,12 \\
\hline C & Sedang & 0 & 0 & 0 & 0 & 0 & 0 & 0 & 0 \\
\hline D & Kurang & 0 & 3,23 & 12,5 & 16,13 & 12,5 & 29,03 & 31,25 & 41,94 \\
\hline E & Sangat kurang & 0 & 0 & 6,25 & 3,23 & 6,25 & 0 & 6,25 & 25,81 \\
\hline
\end{tabular}

Berdasarkan Tabel 1, dapat diketahui bahwa peserta didik kelas eksperimen menghasilkan skor tes kemampuan pemahaman matematis yang berada pada kategori baik dan sangat baik dengan persentase sekitar 84,38\%. Sedangkan untuk kelas kontrol sekitar 64,51\% berada pada kategori baik dan sangat baik dan masih ada peserta didik yang berada pada kategori sangat kurang.

Sedangkan hasil penelitian Mawaddah dan Maryanti (2016) menunjukkan bahwa kemampuan pemahaman konsep matematika peserta didik yang didasarkan indikatorindikator menurut Kurikulum 2013 dalam pembelajaran matematika dengan menggunakan model penemuan terbimbing (Discovery Learning) sebagian besar menghasilkan skor tes kemampuan pemahaman matematis yang berada pada kategori baik dan sangat baik dengan persentase sekitar 89,65\%, dan persentase skor tes Berdasarkan Tabel 2 dapat diketahui bahwa peserta didik di kelas eksperimen secara keseluruhan telah mencapai indikator pemahaman mekanikal dengan persentase terbesar berada pada kriteria sangat baik. Pada indikator pemahaman rasional juga persentase terbesar berada pada kriteria sangat baik, dan persentase terkecil pada kriteria kurang. Pada indikator pemahaman induktif dan indikator pemahaman intuitif persentase terbesar berada pada kriteria baik, dan persentase paling rendah pada kriteria kurang. Sedangkan peserta didik di kelas kontrol secara keseluruhan pada indikator pemahaman mekanikal mempunyai persentase terbesar berada pada kriteria sangat baik, dan persentase terkecil pada kriteria kurang. Pada indikator pemahaman induktif juga persentase terbesar berada pada kriteria sangat baik, dan persentase terkecil pada kriteria sangat kurang. Pada indikator pemahaman rasional persentase terbesar berada pada kriteria baik, dan persentase terkecil pada kriteria kurang. Serta pada indikator pemahaman intuitif persentase terbesar berada pada kriteria kurang.

Sedangkan penelitian analisis yang telah dilakukan oleh Safitri, et.al. (2017) menyebutkan bahwa pemberian tes kemampuan pemahaman matematis peserta didik menurut Polya menggambarkan bahwa masih banyak peserta didik yang masih membuat kesalahan dalam 
menerapkan konsep dalam menyelesaikan soal matematika. Peserta didik juga masih kurang cakap dalam menyelesaikan permasalahan yang diberikan, antara lain sering tidak mencantumkan satuan pada hasil akhir penyelesaian soalnya, juga kurang mampu dalam menjelaskan langkah-langkah penyelesaiannya dan membuktikan kebenaran dari hasil perhitungan yang telah dilakukan, serta ragu- ragu dalam memperkirakan kebenaran hasil jawabannya.

Hasil uji perbedaan dua rata-rata diketahui bahwa jika dilihat rata-rata skor kemampuan pemahaman matematisnya semakin jelas perbedaaannya. Hasil analisis menunjukkan bahwa kemampuan pemahaman matematis peserta didik kelas eksperimen lebih baik daripada kemampuan pemahaman matematis peserta didik kelas kontrol. Sehingga, dapat disimpulkan bahwa kemampuan pemahaman matematis peserta didik dengan penerapan model Discovery Learning berbasis Multiple Intelligences lebih baik daripada kemampuan pemahaman matematis peserta didik dengan penerapan model Discovery Learning. Hal tersebut disebabkan model Discovery Learning berbasis Multiple Intelligences selain dapat memberikan peserta didik pengalaman baru untuk melakukan penemuan yang dapat mengembangkan kemampuan dirinya, dapat pula melibatkan kecerdasan-kecerdasan yang dimiliki oleh setiap peserta didik. Sejalan dengan apa yang dikemukakan Armstrong (2013) yaitu, setiap peserta didik memiliki kecerdasan-kecerdasan yang sama, tetapi dalam hal menonjolkannya berbeda-beda, hal ini dapat mendorong pendidik untuk dapat melibatkan kecerdasan-kecerdasan yang dimiliki oleh setiap peserta didik untuk mencapai tujuan belajarnya (p.5). Hal ini juga sejalan dengan penelitian Hasanah, et.al. (2017) yang menyebutkan bahwa model pembelajaran yang dikombinasikan dengan Multiple Intelligences memberikan pengaruh yang baik jika dibandingkan dengan pembelajaran konvensional.

Multiple Intelligences mempunyai sifat kreatif dan inovatif, sehingga setiap fase pembelajaran model Discovery Learning berbasis Multiple Intelligences dalam proses penemuan terdapat berbagai kegiatan yang dapat melibatkan kecerdasan-kecerdasan yang dimiliki oleh setiap peserta didik. Kegiatan pembelajaran seperti itu membuat lingkungan belajar peserta didik selain terfokus, dapat pula melatih kecerdasan-kecerdasan yang dimilikinya sehingga tidak jenuh. Hal ini sejalan dengan apa yang dinyatakan oleh Suarni (2014) yaitu pembelajaran Multiple Intelligences merupakan pembelajaran yang melibatkan intelektual melalui lingkungan pembelajaran yang memberikan pengalaman belajar yang bermakna (p.63). Hal ini, sejalan dengan hasil penelitian Ariany, et.al.(2017) yang menyebutkan bahwa kemampuan pemahaman matematis berkorelasi positif dengan Multiple Intelligences. Sehingga, dapat ditarik implikasi bahwa kegiatan pembelajaran yang memanfaatkan Multiple Intelligences akan memberikan kontribusi positif terhadap peningkatan kemampuan pemahaman matematis peserta didik, semakin baik kecerdasan-kecerdasan yang dimiliki maka akan semakin baik pula kemampuan pemahaman matematisnya. Selain itu, hasil penelitian Ratnasari (2014) juga menyebutkan bahwa pembelajaran berbasis Multiple Intelligences memberikan pengaruh positif pada kemampuan pemecahan matematik peserta didik dan sikap peserta didik menunjukkan sikap positif terhadap pembelajaran berbasis Multiple Intelligences.

Pada kelas eksperimen, setelah pelaksanaan tes kemampuan pemahaman matematika, maka diberikan angket minat belajar matematika. Hal ini dilakukan, untuk mengetahui minat belajar matematika peserta didik selama penerapan model Discovery Learning berbasis Multiple Intelligences. Hasil perhitungan dan analisis skor angket minat belajar matematika secara keseluruhan dapat disajikan ke dalam Tabel 3: 
Tabel 3. Hasil Perhitungan dan Analisis Skor Angket Minat Belajar Matematika secara Keseluruhan

\begin{tabular}{ll}
\hline Indikator Minat Belajar Matematika & Kriteria \\
\hline Perasaan senang & Tinggi \\
\hline Ketertarikan peserta didik & Tinggi \\
\hline Keterlibatan peserta didik & Tinggi \\
\hline Rajin dalam belajar dan rajin mengerjakan tugas matematika & Sedang \\
\hline Tekun dan disiplin dalam belajar, serta memiliki jadwal belajar & Sedang \\
\hline Rata-rata Keseluruhan & Tinggi \\
\hline
\end{tabular}

Pada indikator perasaan senang, minat belajar matematika yang tinggi ditunjukkan dengan rasa sukanya peserta didik terhadap pembelajaran matematika dengan menerapkan model Discovery Learning berbasis Multiple Inteligences, senang belajar matematika dengan menggunakan media pembelajaran, merasa bahwa pembelajaran seperti itu tidak merepotkan, sehingga lebih menyenangkan daripada pembelajaran yang biasanya dilakukan, sehingga mempermudah dalam mempelajari matematika. Pada indikator ketertarikan peserta didik, minat belajar matematika pada kriteria tinggi ditunjukkan dengan lebih bersemangatnya dalam belajar jika pembelajarannya menerapkan model Discovery Learning berbasis Multiple Inteligences dan berperan aktif dalam kegiatan diskusi kelompok, peserta didik lebih fokus dan terarah dalam belajar di sekolah, merasa bahwa bahan ajar yang disajikan tidak membosankan, lebih mengetahui manfaat belajar yang diperoleh, suasana belajar yang mendukung, serta ada rasa terpacu untuk menunjukkan kemampuan yang terbaik. Pada indikator keterlibatan peserta didik, minat belajar matematika pada kriteria tinggi ditunjukkan dengan adanya kemampuan peserta didik dalam mendemostrasikan media pembelajaran yang telah disediakan, tidak mengacuhkan pertanyaan yang diberikan oleh pendidik, mempunyai rasa peduli jika ada temannya yang tidak bisa matematika, mampu berdiskusi dengan baik bersama teman di dalam kelompoknya, serta adanya rasa keberanian untuk mengemukakan pendapat dan mengerjakan soal di depan kelas. Pada indikator rajin dalam belajar dan rajin mengerjakan tugas matematika, minat belajar matematika pada kriteria sedang ditunjukkan dengan memeriksa kembali tugas matematika sebelum dikumpulkan, mempelajari kembali matematika yang sudah dipelajari di sekolah, mempunyai kemampuan dalam mengerjakan tugas individu secara mandiri dengan cara mencari cara penyelesaian dari berbagai sumber, sehingga dapat menyimpulkan hasil dari pembelajaran matematika. Pada indikator tekun dan disiplin dalam belajar, serta memiliki jadwal belajar, minat belajar matematika pada kriteria sedang ditunjukkan mempersiapkan pemahamannya untuk menghadapi ujian ataupun pertemuan matematika untuk keesokan harinya dengan cara belajar bersama ataupun meminjam catatan dan bertanya kepada teman saat dirinya tidak masuk sekolah. Selain itu, peserta didik juga telah berusaha untuk tidak menunda pengerjaan tugas matematika yang diberika, sehingga mereka belajar matematika tidak hanya saat akan menghadapi ujian saja. Secara keseluruhan dapat diketahui bahwa minat belajar matematika mencapai kriteria tinggi. Hasil penelitian ini jika dibandingkan dengan model Discovery Learning tanpa basis Multiple Intelligences, hasil penelitian Dassa, et.al. (2017) menyebutkan model Discovery Learning secara keseluruhan berada pada kategori tinggi.

\section{SIMPULAN}

Berdasarkan hasil penelitian dan pengolahan data, dapat diperoleh kesimpulan yaitu ada pengaruh positif dari penerapan model Discovery Learning berbasis Multiple Intelligences 
terhadap kemampuan pemahaman matematis peserta didik dan peserta didik yang menerapkan model Discovery Learning berbasis Multiple Intelligences memiliki minat belajar matematika tinggi.

\section{DAFTAR RUJUKAN}

Ariany, R. L., Rachmawati, T. K., \& Agustina, R. D. (2017). Hubungan kemampuan pemahaman matematis dengan multiple intelligences mahasiswa. Seminar Matematika dan Pendidikan Matematika UNY, 641-646.

Armstrong, T. (2013). Kecerdasan multiple di dalam kelas (Prabaningrum, Dyah Widya) (3rd ed.). Jakarta: Indeks.

Dassa, A., Tahmir, S., \& Magfirah, I. (2017). Efektivitas model pembelajaran discovery learning dengan setting kooperatif ditinjau dari kemampuan analogi dan generalisasi matematis siswa kelas VII MTS Al-Fakhriyah Makassar. UNM.

Dwiyana, F. R. (2017). Efektivitas pembelajaran berbasis kecerdasan majemuk ditinjau dari keyakinan siswa terhadap matematika dan prestasi belajar. Jurnal Pendidikan Matematika, 6(5), 47-58.

Gardner, H. (2003). Kecerdasan majemuk (Sindoro, Alexander). Batam, Indonesia:Interaksara.

Gusniwati, M. (2015). Pengaruh kecerdasan emosional dan minat belajar terhadap penguasaan konsep matematika siswa SMAN di kecamatan Kebon Jeruk. Jurnal Formatif, 5(1), 26-41.

Hasanah, L. A., Sudin, A., \& Maulana, M. (2017). Pengaruh pendekatan problem based learning (PBL) berbasis multiple intelligences terhadap kemampuan pemecahan masalah matematis siswa pada materi pecahan kelas IV semester 2. Ejournal.Upi.Edu, 2(1), 1141-1150. Retrieved from: https://doi.org/http://dx.doi.org/10.17509/jpi.v2 i1.11263

Hendriana, H., Rohaeti, E. E., \& Sumarmo, U. (2017). Hard skills dan soft skills matematik siswa. Hard Skills dan Soft Skills Matematik Siswa. Bandung, Indonesia: Refika Aditama.

Illahi, M. T. (2012). Pembelajaran discovery strategy \& mental vocational skill: Tutorial inspiratif bagi para pembelajar. Yogyakarta, Indonesia: Diva Press.

Mawaddah, S., \& Maryanti, R. (2016). Kemampuan pemahaman konsep matematis siswa SMP dalam pembelajaran menggunakan model penemuan terbimbing (discovery learning). EDU-MAT, 4(1), 76-85.

Ratnasari, D. (2014). Pengaruh pembelajaran berbasis multiple intelligences (MI) terhadap kemampuan pemecahan masalah matematik peserta didik (Penelitian ini dilakukan di kelas VIII di SMP Negeri 15 Tasikmalaya). Universitas Siliwangi. Universitas Siliwangi, Tasikmalaya. Indonesia.

Safitri, F. L., Susanto, \& Fatahillah, A. (2017). Analisis pemahaman matematis siswa kelas VIII B SMP negeri 8 Jember berdasarkan Polya dengan pemberian scaffolding pokok bahasan kubus dan balok. Kadikma, 8(2), 151-165.

Suarni, N. K. (2014). Metode pengembangan intelektual. Yogyakarta, Indonesia: Graha Ilmu.

Sunendar, A. (2018). PEMBELAJARAN MATEMATIKA BERBASIS KECERDASAN MAJEMUK. JUMLAHKU: Jurnal Matematika Ilmiah STKIP Muhammadiyah Kuningan, 3(2), 78-89.

Susanto, A. (2016). Teori belajar \& pembelajaran di sekolah dasar. [e-book]. Retrieved from https://books.google.co.id/ books?id=leVNDwAAQBAJ\&printsec=frontcover\&hl=id\#v=onepage \&q\&f=false.

Uno, H. B., \& Kuadrat, M. (2014). Mengelola kecerdasan dalam pembelajaran (1st ed.). Jakarta, Indonesia: Bumi Aksara 